\title{
Zinc Phosphodiesterase ELAC Protein 2
}

National Cancer Institute

\section{Source}

National Cancer Institute. Zinc Phosphodiesterase ELAC Protein 2. NCI Thesaurus. Code C113287.

Zinc phosphodiesterase ELAC protein $2(826 \mathrm{aa}, \sim 92 \mathrm{kDa}$ ) is encoded by the human ELAC2 gene. This protein plays a role in endoribonuclease activity. 